\title{
触 New Disease Reports \\ First report of Sclerotinia rot caused by Sclerotinia sclerotiorum on Lens culinaris in Bangladesh
}

\author{
A.U. Ahmed* and M.A.Y. Akhond
}

Bangladesh Agricultural Research Institute (BARI), Gazipur-1701, Bangladesh

*E-mail: kajalashraf@gmail.com

Received: 11 Mar 2015. Published: 17 May 2015. Keywords: lentil, fungal plant disease

Lentil (Lens culinaris) is an important grain legume with various uses as food and feed because of its protein-rich grains and straw. Globally, it is cultivated as a rainfed crop on 3.85 million ha with a production of 3.59 million tonnes (Erskine et al., 2011). Over the last few years, disease has become a major threat to lentil production in Bangladesh where lentil is grown annually as a major winter-season (rabi) pulse crop. Sixteen diseases have been reported to attack lentil in Bangladesh (Bakr, 1994). Recently, a new disease syndrome (stem, leaf, flower and pod rot) was observed in the Pabna district of the country. In 2014, infection was observed in $80 \%$ of the plants in a 0.5 ha field (Fig. 1).

For pathogen isolation, different parts of the infected plants such as leaf, stem, flower and pod were cut into small pieces and surface sterilised by immersion in $0.5 \%$ sodium hypochlorite for one minute, rinsed three times with sterile distilled water and cultured on potato dextrose agar (PDA), After 11 days fungal colonies developed with white mycelium and produced a ring of large sclerotia at the periphery of the PDA plates. The sclerotia were dark brown to black in colour and medium to large in size (mean $6 \mathrm{~mm}$ ) (Fig. 2). The hyphae were hyaline, branched and multinucleate. The cultural and morphological characteristics of the isolate were recorded for identification. On the basis of morphology, the fungus was identified as Sclerotinia sclerotiorum (Lib.) de Bary (Bolton et al. 2006). The pathogenicity of the fungal isolate was confirmed by reinoculating healthy lentil plants. Inoculum was prepared in wheat bran, tenday-old cultures of which were spread on the surface soil of pots containing 58-day-old lentil plants that were kept at room temperature. After 10 days, stems of the plants were covered by white fluffy mould. Dark brown to black sclerotia were also observed on the soil surface. The inoculated

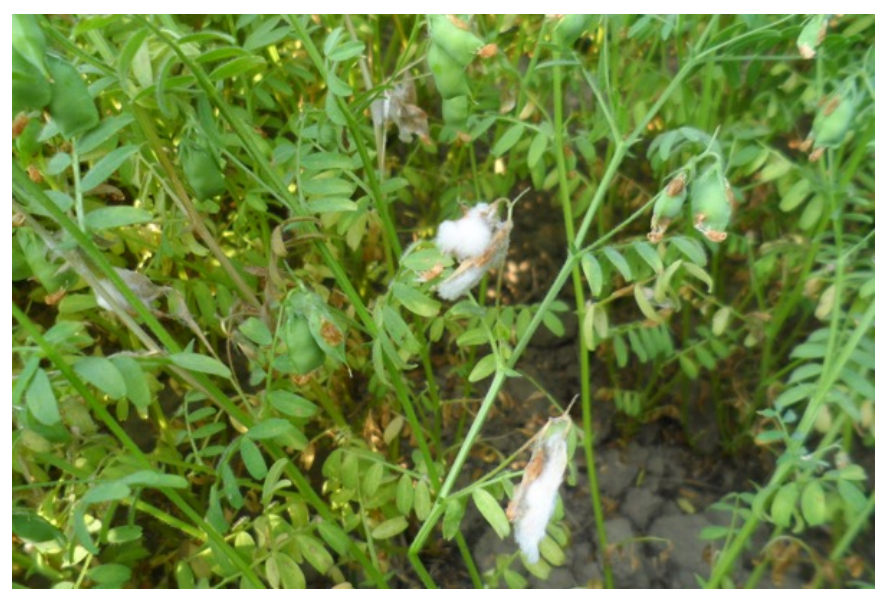

Figure 1

fungus was re-isolated from symptomatic plant parts as previously described. To confirm the identification, genomic DNA was extracted from fresh mycelia grown on PDA plates using a standard plant DNA kit (Geneaid, Taiwan). Internal transcribed spacer (ITS) regions of the nuclearencoded ribosomal RNA genes (rDNA) were amplified using the ITS1-ITS4 primer pair (White et al., 1990) and the amplified PCR product was sequenced. A BLAST search with the 520 bp sequence from the amplicon (GenBank Accession No. KP729418) showed 100\% identity with sequences of Sclerotinia sclerotiorum isolates in the NCBI GenBank. To the best of our knowledge, this is the first report of Sclerotinia rot in Lens culinaris caused by Sclerotinia sclerotiorum in Bangladesh.

\section{References}

Bakr MA, 1994. Check list of pulses diseases in Bangladesh. Bangladesh Journal of Plant Pathology 10, 13-16.

Bolton MD, Thomma BPHJ, Nelson BD, 2006. Sclerotinia sclerotiorum (Lib.) de Bary: biology and molecular traits of a cosmopolitan pathogen. Molecular Plant Pathology 7, 1-16. http://dx.doi.org/10.1111/J.1364-3703.2005.00316.X

Erskine W, Sarker A, Kumar S, 2011. Crops that feed the world 3. Investing in lentil improvement toward a food secure world. Food Security 3, 127-139. http://dx.doi.org/10.1007/s12571-011-0124-5 White TJ, Bruns T, Lee S, Taylor J, 1990. Amplification and direct sequencing of fungal ribosomal genes for phylogenetics. In: Innis MA, Gelfand DH, Shinsky J, White TJ, eds. PCR protocols. A guide to methods and applications. San Diego, CA, USA: Academic Press, 315-322.

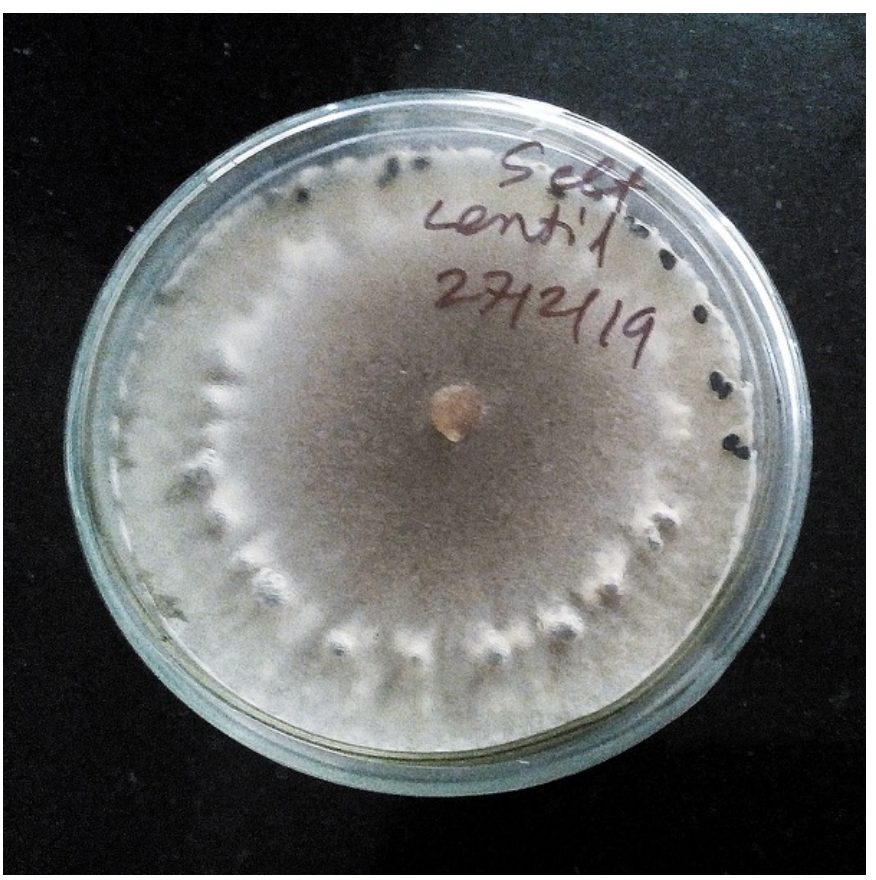

Figure 2

To cite this report: Ahmed AU, Akhond MAY, 2015. First report of Sclerotinia rot caused by Sclerotinia sclerotiorum on Lens culinaris in Bangladesh. New Disease Reports 31, 23. http://dx.doi.org/10.5197/j.2044-0588.2015.031.023

(C) 2015 The Authors

This report was published on-line at www.ndrs.org.uk where high quality versions of the figures can be found. 